\title{
CITY-BASED LEARNING - KONCEPCJA UCZENIA SIĘ POPRZEZ MIASTO. TŁO TEORETYCZNE, PODSTAWOWE ZAŁOŻENIA, PRZYSZŁE KONTEKSTY ROZWOJU I IMPLEMENTACJI
}

\begin{abstract}
Aвstract. Kruszwicka Agnieszka, Klichowski Michał, City-based learning - koncepcja uczenia się poprzez miasto. Tło teoretyczne, podstawowe założenia, przyszłe konteksty rozwoju i implementacji [City-Based Learning Concept. Theoretical Background, Basic Assumptions, Future Contexts of Development and Implementation]. Studia Edukacyjne nr 50, 2018, Poznań 2018, pp. 135-150. Adam Mickiewicz University Press. ISSN 1233-6688. DOI: 10.14746/ se.2018.50.9
\end{abstract}

Currently, over a half of the world's population lives in cities. It is estimated that by 2050 at least 85 per cent of Europeans will have lived in European cities. This trend is related to the fact that today cities are spaces of permanent learning in authentic contexts, which is fostered by the development of new technologies. However, little is known about the city-based learning concept, which is crucial for this type of technology-enhanced learning. Here, we discuss the theoretical background, basic assumptions and future contexts of development and implementation of this idea. Firstly, we demonstrate that city-based learning is contingent on such theories as urban studies, pedagogy of place, as well as urban education, explorative learning, learning outside the classroom, mobility of learning space or on-street activity. Secondly, we show that smartphones, tablets, GPS, educational cloud, and digital textbooks are technologies for city-based learning. We conclude that cities connected to an educational cloud (which is full of educational resources and serves as a platform for educational communication) are unique environments for students equipped with mobile tools. Finally, we point out a new project on a city-based learning implementation.

Key words: pedagogy of place, urban education, technology-enhanced learning, educational cloud

\section{Wprowadzenie}

Ponad połowa ludzi zamieszkuje obecnie miasta (prawdopodobnie ponad pięćdziesiąt pięć procent) ${ }^{1}$. Ten pięćdziesięcioprocentowy próg został

${ }^{1}$ H. Quak i in., From freight partnerships to city logistics living labs - giving meaning to the elusive concept of living labs, Transportation Research Procedia, 2016, 12, s. 462; R. Khatoun, S. Ze- 
przekroczony już w roku $2007^{2}$. W samej Europie statystyki te są jeszcze wyższe: pięćdziesiąt procent osiągnęliśmy już w roku 1950, a obecnie w miastach mieszka ponad siedemdziesiąt pięć procent Europejczyków (w Polsce ponad sześćdziesiąt procent) $)^{3}$. Szacuje się ponadto, że do roku 2050 światowa populacja zamieszkująca miasta wzrośnie (w porównaniu z obecną liczbą) o blisko sześćdziesiąt pięć procent ${ }^{4} \mathrm{i}$ że $\mathrm{w}$ miastach mieszkać będzie co najmniej osiemdziesiąt pięć procent ludności Starego Kontynentu ${ }^{5}$.

Taka tendencja rozwoju naszej cywilizacji jest wynikiem tak zwanej trzeciej rewolucji urbanistycznej (the third revolution in urbanization) $)^{6}$. Prymarna rewolucja urbanistyczna miała miejsce $\mathrm{w}$ Antyku, kiedy to powstawały pierwsze miasta. Druga, związana z rewolucją przemysłową, odnosiła się głównie do rozwoju terytorialnego miast i komunikacji między nimi. Trzecia rozpoczęła się natomiast po II Wojnie Światowej, kiedy miasta zaczęły rozwijać się w sposób niepasywny, a zatem - nie tylko jako terytoria osadnicze, ale także jako skupiska stymulantów kreatywności, innowacji, niekonwencjonalnych rozwiązań, oraz przestrzenie nastawione na wiedzę. Szczególnie przełom XX i XXI wieku stanowił okres rozkwitu miasta jako obszaru „inteligentnego" (smart) ${ }^{7}$, w którym różnego typu urbanistyczne czy architektoniczne rozwiązania wspierają intelektualny rozwój jego użytkowników ${ }^{8}$. Od roku 2011 obserwujemy natomiast istną eksplozję technologicznego obudowywania miast, ukierunkowaną między innymi na to, by miasta stały się terenami permanentnego uczenia się społeczeństwa ${ }^{9}$. Technologie zaczynają więc być integrowane $\mathrm{z}$ wszelkimi procesami występującymi $\mathrm{w}$ mieście ${ }^{10}$, stymulując tym samym poznawczy rozwój jego mieszkańców ${ }^{11}$.

adally, Smart cities: concepts, architectures, research opportunities, Communications of the ACM, 2016, 59, s. 46.

${ }^{2}$ K. Kourtit, P. Nijkamp, D. Arribas, Smart cities in perspective - a comparative European study by means of self-organizing maps, Innovation: The European Journal of Social Sciences, 2012, 25, s. 229.

${ }^{3}$ Powierzchnia i ludność w przekroju terytorialnym w 2018 r., Warszawa 2018.

${ }^{4} \mathrm{~L}$. Gong i in., A satisfaction analysis of the infrastructure of country parks in Beijing, Urban Forestry \& Urban Greening, 2015, 14, s. 480.

${ }^{5}$ A. Caragliu, C. Del Bo, P. Nijkamp, Smart cities in Europe, Journal of Urban Technology, 2011, 18, s. 65-66.

${ }^{6}$ K. Kourtit, P. Nijkamp, D. Arribas, Smart cities in perspective, s. 229.

7 I. Semanjski, S. Gautama, Smart city mobility application - gradient boosting trees for mobility prediction and analysis based on crowdsourced data, Sensors, 2015, 15, s. 15975.

${ }^{8}$ G. Mone, The new smart cities, Communications of the ACM, 2015, 58, s. 20.

${ }^{9} \mathrm{~S}$. Hajduk, The concept of a smart city in urban management, Business, Management \& Education, 2016, 14, s. 36.

${ }^{10}$ B. Gontar, Z. Gontar, A. Pamula, Deployment of smart city concept in Poland. Selected aspects, Management of Organizations: Systematic Research, 2013, 67, s. 41.

${ }_{11}$ L.G. Cretu, Smart cities design using event-driven paradigm and semantic web, Informatica Economica, 2012, 16, s. 57. 
Współczesne miasto stanowi zatem miasto uczenia się ${ }^{12}$ czy centrum edukacji (a centre for education) ${ }^{13}$. I nie chodzi tu tylko o formalną edukację uczniów w wieku szkolnym, ale także o uczenie się w autentycznym otoczeniu wszystkich miastowych, bez względu na ich wiek i edukacyjny status $^{14}$. Ważną osią oscylacji obecnego miasta jest więc nieformalne uczenie się „o mieście”, oparte na zaimplementowanych w tkankę miejską technologiach, które wykorzystać może każdy obywatel miasta ${ }^{15}$. Celem tego artykułu jest omówienie koncepcji takiego, opartego na mieście (city-based), uczenia się. Wcześniej jednak ukażemy tło tego pomysłu, a więc czym jest miasto jako takie i jakie jest jego miejsce w dyskursie pedagogicznym. Artykuł zakończy wzmianka o projekcie naukowym, którego realizacja powinna usystematyzować ideę uczenia się opartego na mieście (city-based learning) oraz zweryfikować jej założenia empirycznie.

\section{Teoretyczne tło koncepcji}

\section{Czym jest miasto?}

Miasto istnieje w powszechnej świadomości jako miejsce koncentracji ludzi, technologii oraz różnych dóbr. W potocznym rozumieniu, jest to jednostka osadnicza charakteryzująca się dużą intensywnością zabudowy. Każdy człowiek potrafi odróżnić je od wsi i intuicyjnie rozumie jego istotę. Jednakże, na pytanie o definicję miasta bardzo trudno udzielić precyzyjnej odpowiedzi, bowiem jego naturą jest ciągłe przeobrażanie czy nieustanne stawanie się. Proces rozumienia miasta wydaje się jakby „immanentnie otwartym” ${ }^{16}$.

W średniowieczu podstawą, na której oparto definicję miasta była arbitralna władza - uznawano, że „miastem jest ta miejscowość, której nadano odpowiednie prawa"17. Początek rozkwitu zainteresowania miastem jako kategorią, którą należy badać naukowo, nastąpił jednak dopiero na przełomie XIX i XX wieku. Wtedy to wielcy socjologowie, jak Weber, Ezra Park, czy Znaniecki, sformuło-

12 S. Kraus i in., Innovating and exploiting entrepreneurial opportunities in smart cities: evidence from Germany, Creativity \& Innovation Management, 2015, 24, s. 602; E. Tranos, D. Gertner, Smart networked cities? Innovation: The European Journal of Social Sciences, 2012, 25, s. 176

13 P. Goswami, Matrix for a smart city, Current Science, 2015, 109, s. 246.

14 M. Thite, Smart cities: implications of urban planning for human resource development, Human Resource Development International, 2011, 14, s. 627.

${ }^{15}$ L. Batagan, Smart cities and sustainability models, Informatica Economica, 2011, 15, s. 83; H. Tong, Y. Feng, Smart education and legal governance, 3rd International Conference on Science and Social Research, 2014, s. 392-394.

${ }^{16}$ K. Kamińska, Wstęp. O dyskursach edukacyjnych w przestrzeni miejskiej, [w:] Miejskie wojny. Edukacyjne dyskursy przestrzeni, red. K. Kamińska, Wrocław 2011, s. 12.

17 B. Jałowiecki, Miasto i społeczne problemy urbanizacji, problemy, teorie, metody, Warszawa 1972 , s. 8. 
wali własne koncepcje tego terminu, uwzględniające różne składniki, jednak zawsze podkreślające społeczny charakter miasta. Wśród współczesnych definicji można znaleźć zarówno te bardzo ogólne, jak na przykład Wolańskiego, który określa miasto „dużym stałym skupiskiem ludności i zabudowy"18, oraz rozbudowane, uwzględniające liczne czynniki pokazujące złożoność miasta i jego wielowymiarowość, jak choćby ta Paszkowskiego:

miasto jest tworem przestrzenno-społecznym o wysokiej złożoności, powstałym w określonych warunkach politycznych, społecznych i ekonomicznych, w konkretnej przestrzeni. Miasto to przestrzeń zurbanizowana, która była tworzona w sposób nierównomierny $\mathrm{w}$ czasie, na określonej przestrzeni, ulegając procesom rozwoju, przekształceń i degradacji. Miasto stanowi wyraz przestrzenny zrealizowanych idei i podjętych decyzji w zakresie urbanistycznym i społecznym. Miasto jest odzwierciedleniem działania sił rynkowych w czasie i przestrzeni, w której zapisane są zarówno okresy gospodarczego wzrostu, jak i kryzysów gospodarczych i politycznych. Miasto jako przestrzeń społeczno-kulturowa jest miejscem wymiany myśli i rozwoju cywilizacyjnego, odzwierciedlającym dążenia, aspiracje i kulturę jego mieszkańców ${ }^{19}$.

$\mathrm{Z}$ biegiem lat miasto stało się przedmiotem badań wielu dyscyplin nauki, które badały je z odmiennych perspektyw. Na początku XXI wieku zaczęto jednak dostrzegać fakt, że miasto stanowi interdyscyplinarną kategorię, którą należy badać holistycznie. W efekcie tego, w USA oraz na zachodzie Europy powstały Urban Studies, czyli tak zwane studia miejskie ${ }^{20}$ (ryc. 1).

Z problemem w definiowaniu miejskości mierzą się także państwa, które nadając miejscowościom status miasta, muszą kierować się odpowiednimi kryteriami. To co w jednym kraju stanowi o miejskości danej jednostki, w innym może być potraktowane jako mało istotne. Jednak niezależnie od tego, jakie kryterium zostanie uznane za pryncypialne, można zaobserwować nieustanny wzrost urbanizacji świata.

Dążenie do mieszkania w mieście nie jest czymś nowym. Prawa miejskie od zawsze były źródłem wielu przywilejów, włodarze miast dbali o ich utrzymanie, traktując je jako jedno z najwyższych dóbr. Nadanie miejscowości statusu miasta wiązało się z prestiżem, podnosiło rangę i wartość zarówno terenu, na którym było ulokowane, jak i jego mieszkańców, którzy w ten sposób wchodzili w elitarny stan mieszczaństwa. Cieszyli się oni poważaniem, szczególnymi względami u władcy, uzyskiwali specjalne pozwolenia, dzięki

${ }^{18}$ N. Wolański, Miasto jako przedmiot badań ekologii człowieka, [w:] Miasto jako przedmiot badań naukowych - refleksje po 10 latach, red. B. Jałowiecki, Katowice 1982, s. 48.

19 Z. Paszkowski, Miasto idealne w perspektywie europejskiej i jego związki z urbanistyką wspótczesna, Kraków 2011, s. 16-17.

20 B. Jałowiecki, Przedmowa, [w:] Miasto jako przedmiot badań naukowych w poczatkach XXI wieku, red. B. Jałowiecki, Warszawa 2008, s. 8; tenże, Wspólne i odrębne płaszczyzny badań, [w:] Miasto jako przedmiot badań naukowych, s. 195-196. 


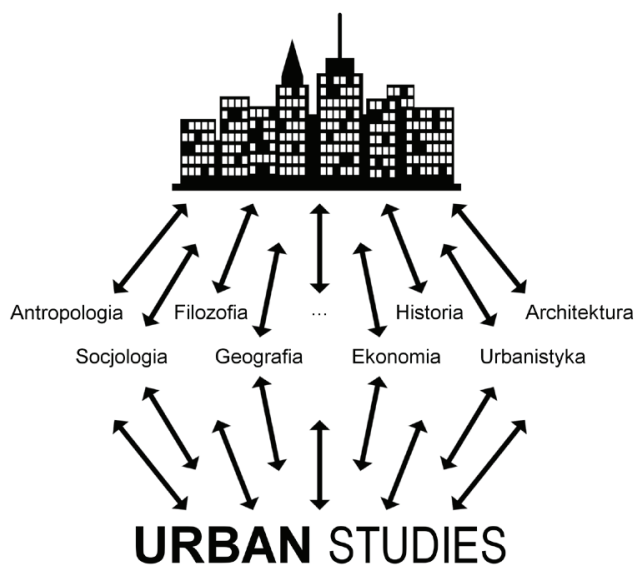

Ryc. 1. Interakcja między miastem, dyscyplinami nauki a Urban Studies

Miastem zajmuje się wiele dyscyplin nauki, a te wymienione na rycinie stanowią jedynie część tego zbioru. Zintegrowanie ich wokół wspólnego przedmiotu badań doprowadziło do powołania Urban Studies. Powiązania są tu dwukierunkowe - to co jest tworzone przez dane elementy, jednocześnie je kreuje

którym mogli wieść wygodne życie, wobec czego ściśle pilnowano składu tych grup społecznych i rzadko kiedy wprowadzano do nich kogoś z zewnątrz. Takie wyjątkowe traktowanie mieszczan trwało przez stulecia i dopiero w XIX wieku miasta otworzyły się na nowych mieszkańców, migrujących z biednych obszarów wiejskich. Z czasem więc elitarność miast przeobraziła się w ich egalitarność. Pozostały one jednak miejscami oferującymi „skoncentrowaną lokalnie sumę korzyści, zdolnych przeważyć niedogodności zatłoczenia, hałasu, ciasnoty, tłoku, zachowania sąsiadów itp." 21 Miasta postrzegane są nadal jako obrazy osiągnieć danych społeczeństw ${ }^{22}$ i zapisy ich historii ${ }^{23}$. Pęd do miejskiego życia nie stracił więc na aktualności. Nabrał jednak innego wymiaru, bardziej powszechnego, dostępnego dla szerokich mas ludzi.

Ludzkie życie zawsze odbywa się w jakimś miejscu, jest z nim powiązane i zakotwicza się w nim²4. Miejsce stanowi lokalizację „obdarzoną osobistym lub kulturowym znaczeniem” 25 i „w przeciwieństwie do anonimowych ob-

${ }^{21}$ M. Czornik, Miasto i jego produkty, Studia Ekonomiczne, 2013, 147, s. 36.

${ }_{22}$ M. Gaj, K. Kamińska, Miasto - nowe pogranicze. Wyzwania dla krytycznej pedagogiki miejsca, [w:] Miejskie opowieści edukacyjne narracje przestrzeni, red. K. Kamińska, Wrocław 2010, s. 103.

23 B. Jałowiecki, Czytanie przestrzeni, Kraków - Rzeszów - Zamość 2012, s. 272.

${ }_{24}$ M. Mendel, Pedagogika miejsca i animacja na miejsce wrażliwa, [w:] Pedagogika miejsca, red. M. Mendel, Wrocław 2006, s. 21.

${ }^{25}$ W. Danilewicz, Doświadczenia miejsca w przestrzeni globalnej - perspektywa pedagogiczna, [w:] Pedagogika społeczna. Pamięć: przeszłość - teraźniejszość - przyszłość, red. W. Danilewicz, W. Theiss, Warszawa 2016, s. 83. 
szarów, przestrzeni czy terytoriów jest strukturą własną, osobistą, indywidualną, organizowaną wokół przyjmowanych wartości"26. W miejscu można się ponadto kulturowo zakorzenić, można naznaczyć je kulturowymi symbolami, poprzez które wpisuje się w nie przeszłość, emocje i przeżycia. Tym samym, miejsca charakteryzuje genius loci, czyli własny duch ${ }^{27}$. Miasto nie może więc istnieć bez miejsc. Miejsca są jakby podstawową składową miasta - miasto jest "miejscem miejsc” ${ }^{28}$. Ponieważ składa się ono z takich miejsc, „które dla ludzi są ważne” i „,budzą emocje” ${ }^{29}$, miasto nieustannie oddziałuje na człowieka. Człowiek tworząc miasto, tworzy więc jakby kronikę rozwoju ludzkości oraz miejsca własnego rozwoju ${ }^{30}$.

\section{Miasto jako kategoria pedagogiczna}

W pedagogice kategorii miasta nie poświęcono dotychczas zbyt wiele uwagi, wręcz można by pokusić się o stwierdzenie, że jest ona tu marginalizowana. Na interdyscyplinarnych konferencjach poświęconych miastu, bądź w publikacjach dotyczących tego zagadnienia, bardzo rzadko pojawiają się nazwiska pedagogów. Dopiero w ostatnich latach rozpoczął się powolny zwrot pedagogiki ku miastu; podjęto badania nad nim z perspektywy pedagogiki. W Polsce niewątpliwie prekursorem tych działań jest M. Mendel, która zorientowała swe dociekania wokół miejsca, częściowo poświęcając je stricte miastu. Szczególną uwagę zwróciła na relację podmiot - miejsce, podkreślając wychowawczy charakter miejsca. Autorka zaproponowała, aby ten wycinek pedagogiki nazwać pedagogika miejsca. Ma ona być nurtem

interdyscyplinarnych w swojej istocie penetracji przestrzeni i przestrzenności świata. Niezależnie od kartezjańskich podziałów, dla nas ludzi zawsze jest on po prostu ludzki. Uczymy się go w każdej chwili życia, wchodzimy w dialektyczny związek z miejscami, które formują nas i które kształtujemy nieustannie. Stąd ów szyld pedagogiki miejsca ${ }^{31}$.

Mendel określa ją ponad to jako „działanie miejscem, albo działanie miejsca, które wywołuje autokreację podmiotu” ${ }^{32}$. Taki wychowawczy charakter miejsca, a co za tym idzie miasta, potwierdzają także inni autorzy. W. Danilewicz twierdzi na przykład, że „miejsce wychowuje i powinno być utożsamiane z wychowaniem; staje się w ten sposób miejscem wychowującym" ${ }^{\prime 3}$. I. Copik pisze natomiast, że miejsce „jest istotne nie tylko dlatego, że wychowujemy

${ }^{26}$ W. Theiss, Dom i ojczyzna - miejsca w świecie bez miejsc. Trzy perspektywy, [w:] Dom i ojczyzna dylematy wielokulturowości, red. D. Lalak, Warszawa 2008, s. 77-78.

27 M. Lewicka, Psychologia miejsca, Warszawa 2012, s. 61.

28 Y-F. Tuan, Space and place, London 1977, s. 3.

29 B. Jałowiecki, Miejsce, przestrzeń, obszar, Przegląd Socjologiczny, 2011, 2, s. 17.

${ }^{30}$ W. Theiss, Dom i ojczyzna - miejsca w świecie, s. 78.

31 M. Mendel, Społeczeństwo i rytuat. Heterotopia bezdomności, Toruń 2007, s. 11.

32 Tamże, s. 28.

${ }^{33}$ W. Danilewicz, Doświadczenia miejsca w przestrzeni globalnej, s. 88-89. 
w/dla/poprzez nie, wykorzystując zbiór wartości w nim uobecnionych, ale jest ważne, ponieważ ono wychowuje nas" ${ }^{34}$.

Jakie zadania ma zatem pedagogika miejsca wobec miasta? Wielu badaczy mierzy się z odpowiedzią na to pytanie, lecz trudno tu o odpowiedź, którą można by uznać za wyczerpującą ${ }^{35}$. Próbę usystematyzowania zadań pedagogiki miejsca wobec miasta, z podziałem na trzy główne obszary działań podejmowanych przez pedagogów, przedstawiono na rycinie 2.

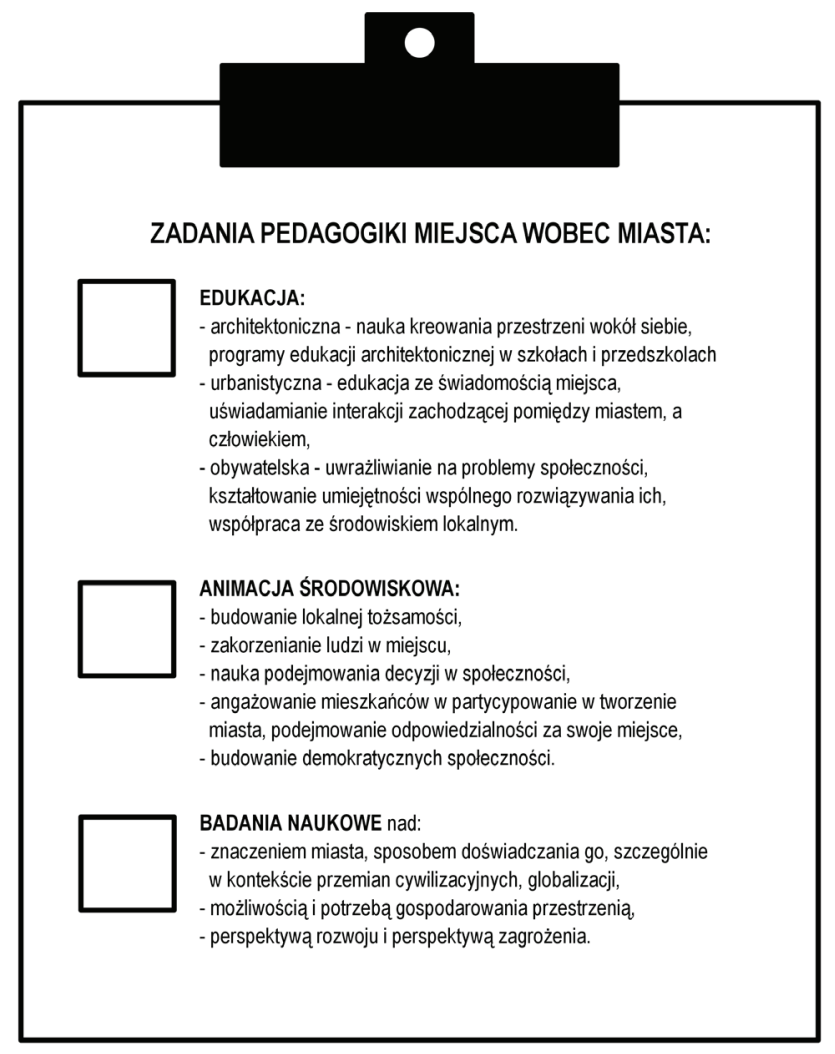

Ryc. 2. Zadania pedagogiki miejsca wobec miasta

Zadania pedagogiki miejsca wobec miasta koncentrują się wokół trzech obszarów działań: (1) edukacyjnych, (2) animacji środowiskowej i (3) badań naukowych. Każdy z nich jest równie ważny i pozostaje z innymi w interakcji

${ }^{34}$ I. Copik, Pedagogika miejsca - kultura lokalna a kształtowanie się tożsamości wspótczesnego człowieka, [w:] Pedagogika, t. XXII, red. K. Rędziński, M. Łapota, Częstochowa 2013, s. 182.

35 Tamże; W. Danilewicz, Doświadczenia miejsca w przestrzeni globalnej, s. 91-92; K. Kamińska, Wstęp. O dyskursach edukacyjnych, s. 9-17; M. Popow, Organizacje pozarządowe, miasta $i$ zmiana społeczna, Studia Pedagogiczne, LXIX, 2016, s. 173; D. Gruenewald, The Best of Both Worlds: A Critical Pedagogy of Place, Educational Researcher, 2003, 32, s. 1011; J. Hajduczenia, Przestrzeń i edukacja: podróż edukacyjna jako rytuał przejścia, Teraźniejszość - Człowiek - Edukacja: kwartalnik myśli społeczno-pedagogicznej, 2009, 3, s. 145-158. 


\section{City-based learning, czyli uczenie się poprzez miasto}

Koncepcja city-based learning zakłada, że wszystko co znajduje się w przestrzeni miasta, konstytuuje unikatowe środowisko uczenia się $e^{36}$, przepełnione zróżnicowanymi obiektami pobudzającymi do aktywności poznawczej ${ }^{37}$. Miasto jest więc tu samo w sobie zasobem edukacyjnym, a jego kulturowe dziedzictwo stanowi pewnego typu historię, którą można odczytywać i eksplorować38. Używając słów Toporowa, „miasto jest tekstem” ${ }^{39}$. Jego układ urbanistyczny i architektura są nośnikami komunikatów, których odpowiednie odczytywanie prowadzi do poszerzania wiedzy. Mowa więc tutaj o eksploracyjnym uczeniu się $e^{40} \mathrm{~W}$ naturalnym otoczeniu ${ }^{41}$.

Ponieważ city-based learning wymaga, aby miasto (jako zasób edukacyjny) zostało w pewnym sensie udostępnione (city-to-share/city2share) uczącym $\operatorname{się}^{42}$, do jego realizacji potrzebne jest wykorzystanie nowych, mobilnych narzędzi technologicznych oraz innowacyjnej technologicznie infrastruktury ${ }^{43}$. Dwoma kluczowymi technologiami są tu edukacyjne chmury i multimedialne przewodniki ${ }^{44}$.

Chmura edukacyjna stanowi technologię umożliwiającą umieszczenie materiałów edukacyjnych w dowolnych formatach, w cyfrowej przestrzeni, do której dostęp mają wszyscy uczestnicy procesu uczenia się, w dowolnym czasie, bez konieczności pobierania tych materiałów na aktualnie wykorzystywa-

36 S.J. Cooley, M.J. Holland, J. Cumming, Introducing the use of a semi-structured video diary room to investigate students' learning experiences during an outdoor adventure education groupwork skills course, Higher Education: The International Journal of Higher Education and Educational Planning, 2014, 67, s. 119.

37 S.M. Land, H.T. Zimmerman, Socio-technical dimensions of an outdoor mobile learning environment: a three-phase design-based research investigation, Educational Technology Research and Development, 2015, 63, s. 233.

38 A. Ya'acob, N. Nor, H. Azman, Implementation of the Malaysian smart school: an investigation of teaching-learning practices and teacher-student readiness, Internet Journal of e-Language Learning \& Teaching, 2005, 2, s. 17.

${ }^{39}$ K. Kamińska, Wstęp. O dyskursach edukacyjnych.

40 D. Igoe, A. Parisi, B. Carter, Smartphones as tools for delivering sun-smart education to students, Teaching Science: The Journal of the Australian Science Teachers Association, 2013, 59, s. 37.

41 P.-H. Hung i in., Seamless connection between learning and assessment-applying progressive learning tasks in mobile ecology inquiry, Educational Technology \& Society, 2013, 16, s. 195-196.

42 J.A. Gonzalez-Martinez i in., Cloud computing and education: a state-of-the-art survey, Computers \& Education, 2015, 80, s. 135.

43 C.-H. Su, C-H. Cheng, A mobile gamification learning system for improving the learning motivation and achievements, Journal of Computer Assisted Learning, 2015, 31, s. 268; M. Perez-Sanagustin i in., Using $Q R$ codes to increase user engagement in museum-like spaces, Computers in Human Behavior, 2016, 60, s. 73.

${ }^{44}$ M. Klichowski i in., CyberParks as a new context for smart education: theoretical background, assumptions, and pre-service teachers' rating, American Journal of Educational Research, 2015, 3, s. 3; M. Klichowski, Learning in CyberParks. A theoretical and empirical study, Poznan 2017, s. 132135. 
ne urządzenie. Jedynym warunkiem jest posiadanie urządzenia z dostępem do Internetu (typu smartphone czy tablet ${ }^{45}$ ) i podłączenie go do tej chmury. Urządzenie automatycznie "prezentuje” konkretne materiały z chmury, dobierając je na bazie informacji o położeniu użytkownika (z wykorzystaniem technologii GPS). Tym samym, osoba eksplorująca miasto, symultanicznie otrzymuje informacje o nim. Informacje te muszą mieć jednak odpowiednią, przyjazną uczeniu się, formę ${ }^{46}$. Tu właśnie z pomocą przychodzi technologia multimedialnych, cyfrowych przewodników/podręczników. Dzięki niej, treści są eksportowane z chmury w atrakcyjny, multimedialny sposób; ponadto są interaktywne, a zatem uczący się ma możliwość dodawania własnych notatek, tworzenia linków, a nawet modyfikowania samych treści ${ }^{47}$.

Podsumowując powyższej zarysowane tezy, można określić, iż city-based learning odnosi się do wizji uczenia się w autentycznym środowisku miasta, poprzez wszelkiego rodzaju mobilne narzędzia cyfrowe (np. smartphony czy tablety) podłączone do edukacyjnej chmury, pełnej materiałów o danym mieście, i stanowiącej ponadto platformę komunikacji oraz społecznościowego doskonalenia edukacyjnych materiałów ${ }^{48}$. City-based learning wpisuje się więc w coraz popularniejsze obecnie koncepcje technologicznie wspomaganego uczenia się na zewnątrz (technology-enhanced outdoor learning) ${ }^{49}$ i edukacji miejskiej (urban education) ${ }^{50}$, czy w szersze idee mobilnych przestrzeni uczenia

45 B.H. Kim, S.Y. Oh, A study on the SMART education system based on cloud and n-screen, Journal of the Korea Academia-Industrial Cooperation Society, 2014, 15, s. 139-142.

${ }^{46}$ J.-S. Jeong, M. Kim, K.-H. Yoo, A content oriented smart education system based on cloud computing, International Journal of Multimedia and Ubiquitous Engineering, 2013, 8, s. 313-325; J.A. Gonzalez-Martinez i in., Cloud computing and education, s. 132; S. Jang, Study on service models of digital textbooks in cloud computing environment for SMART education, International Journal of u- and e- Service, Science and Technology, 2014, 7, s. 77-78.

${ }^{47}$ J.-K. Kim i in., Effect of enhancing learning through annotation similarity and recommendation system, International Journal of Smart Home, 2013, 7, s. 271-281; S. Jang, Study on service models, s. 75-77.

${ }^{48}$ M. Klichowski, C. Smaniotto Costa, How do pre-service teachers rate ICT opportunity for education? A study in perspective of the SCOT theory, Culture and Education, 2015, 4, s. 158; M. Klichowski i in., CyberParks as a new context for smart education, s. 3-5.

${ }^{49} \mathrm{~K}$. Murai i in., Basic evaluation of performance of bridge resource teams involved in on-board smart education: lookout pattern, Review of the Faculty of Maritime Sciences, Kobe University, 2006, 3, s. 77-83; M. Klichowski, Learning in CyberParks, s. 117-143; M. Klichowski, C. Patricio, Does the human brain really like ICT tools and being outdoors? A brief overview of the cognitive neuroscience perspective of the CyberParks concept, [w:] Enhancing Places through Technology. Proceedings from the ICiTy conference, red. A. Zammit, T. Kenna, Lisbon 2017; P. Bonanno, M. Klichowski, P. Lister, A pedagogical model for CyberParks, [w:] CyberParks - the interface between people, places and technology, red. C. Smaniotto Costa, I. Suklje-Erjavec, Springer 2018; M. Klichowski, Learning in hybrid spaces as a technology-enhanced outdoor learning: Key terms, [w:] Neighbourhood E City Between digital and analogue perspectives, red. M. Menezes, C. Smaniotto Costa, Lisbon 2018.

50 C. Smith i in., Designing for active learning: putting learning into context with mobile devices, [w:] Informed design of educational technologies in higher education: enhanced learning and teaching, red. A.D. Olofsson, J.O. Lindberg, Hershey 2012, s. 329. 
się (mobility of learning space) ${ }^{51}$ i poznawczych aktywności na miejskich ulicach (on-street activity) ${ }^{52}$. Rycina 3 stanowi graficzne podsumowanie rozważań tego artykułu.

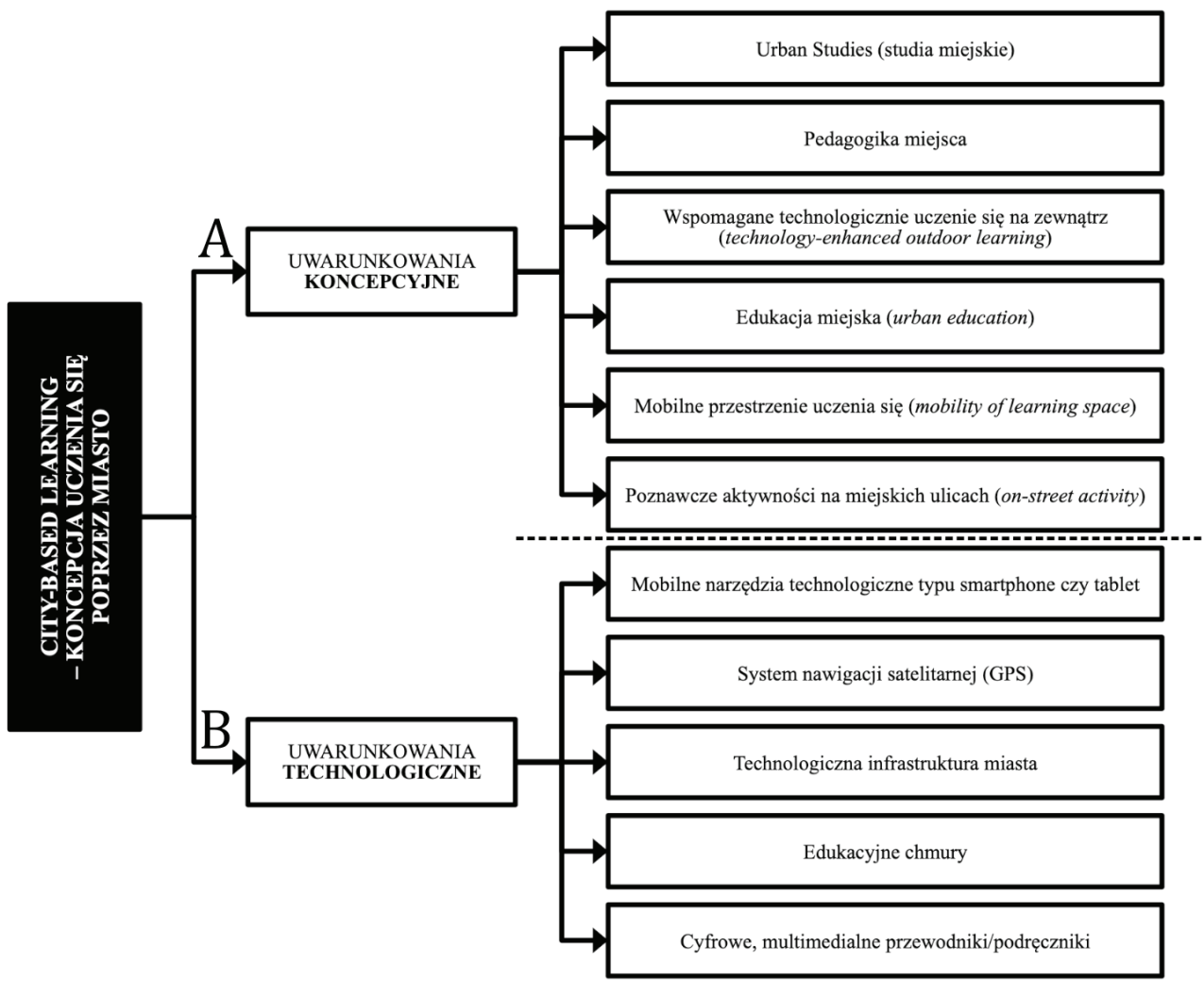

Ryc. 3. Uwarunkowania koncepcji city-based learning (uczenia się poprzez miasto)

(A) Do głównych uwarunkowań koncepcyjnych, wynikających z teoretycznego osadzenia tej koncepcji, zaliczyć można zarówno klasyczne obszary studiów pedagogicznych, takie jak pedagogika miejsca czy edukacja miejska, ale także nowsze i wciąż niemieszczące się w głównym nurcie pedagogiki koncepcje (m.in.) mobilnych przestrzeni uczenia się czy wspomaganego technologicznie uczenia się na zewnątrz. (B) Do ważniejszych uwarunkowań technologicznych, czyli pewnego typu techno-minimów idei city-based learning, zaklasyfikować można powszechne urządzenia mobilne wykorzystujące GPS typu smartphone, ale także innowacyjne technologie chmur edukacyjnych, działające przy współpracy z zaawansowaną technologiczną infrastrukturą miasta

${ }^{51}$ S.H. Kim, N.H. Park, K.H. Joo, Effects of flipped classroom based on smart learning on selfdirected and collaborative learning, International Journal of Control \& Automation, 2014, 7, s. 72.

${ }^{52}$ Z. Samadi i in., Experiencing urban through on-street activity, Procedia - Social and Behavioral Sciences, 2015, 170, s. 653-658. 


\section{Podsumowanie i dalsze zadania}

City-based learning stanowi koncepcję uczenia się poprzez środowisko miasta, z wykorzystaniem wszelkiego rodzaju mobilnych narzędzi cyfrowych, takich jak smartphony czy tablety, podłączanych do edukacyjnej chmury, pełnej materiałów o danym mieście. Kulturowy tekst miasta jest więc tu niejako udostępniony użytkownikom miasta - scyfryzowany i umieszczony w cyfrowej chmurze. Nasuwa się jednak pytanie: Kto ma konstruować takie cyfrowe materiały o mieście? Ponadto, jak to zrobić, by „udostępnianie” miasta nie doprowadziło do jakiegoś paradoksalnego jego zamknięcia się na uczących, jak ma to miejsce na przykład z wieloma terenami zielonymi miasta, gdzie coraz szczegółowsze ich udostępnianie doprowadza do tego, że zamiast być cichymi miejscami odpoczynku na łonie natury, stają się głośnymi skwerami pędzących cyklistów, czy gimnastykujących się przy akompaniamencie „pobudzającej” muzyki z przenośnego głośniczka crossfiterów ${ }^{53}$ ?

Twórcami „contentu” city-based learning mogą stać się organizacje pozarządowe, stowarzyszenia i fundacje, działające lokalnie na rzecz swoich społeczności. Stają się one bowiem współcześnie, obok struktur władz państwowych i miejskich, coraz ważniejszym agentem zmian społecznych, pobudzając ludzi do działania, uświadamiając możliwości i potencjał tkwiący w społecznościach, stanowią niekiedy źródło „oddolnej demokratyzacji przestrzeni” ${ }^{54}$. To one często dbają o podnoszenie standardu życia mieszkańców, wprowadzają innowacje, czasami wręcz bawiąc się środkami wyrazu, zamieniając miasta w swoisty playground, włączając tym samym odbiorców - mieszkańców i turystów - do gry czy interakcji z nim, w myśl zasady, że miejsca „są tym, czym czynią je ludzie" 55 . Ludzie mają przecież prawo do miasta, prawo do decyzji i możliwości wpływania na miasto. Ideę prawa do miasta stworzył Lefebvre w latach sześćdziesiątych XX wieku jako wołanie i żądanie zmian wobec egzystencjalnego kryzysu, w którym pogrążył się ówczesny Paryż ${ }^{56}$. Był to wyraz jego niezgody na „neoliberalną, postdemokratyczną formułę zarządzania współczesnymi miastami, niepozostawiającą miejsca na ich współkreację ze strony mieszkańców" ${ }^{57}$. Po okresie zapomnienia, na początku XXI wieku, Harvey przypomniał ten koncept, domagając się miasta bliskiego sercu jego

${ }^{53}$ F. Aletta, T. Van Renterghem, D. Botteldooren, Influence of personal factors on sound perception and overall experience in urban green areas. A case study of a cycling path highly exposed to road traffic noise, International Journal of Environmental Research and Public Health, 2018, 15.

${ }^{54}$ K. Miciukiewicz, Miasto jako społeczna reprodukcja przestrzeni i kontrprzestrzeni miejsc, [w:] Pedagogika miejsca, red. M. Mendel, Wrocław 2006, s. 212.

55 M. Mendel, Kategoria miejsca w pedagogice, [w:] Tamże, s. 23.

56 D. Harvey, Bunt Miast. Prawo do miasta i miejska rewolucja, Warszawa 2012, s. 8.

57 M. Mendel, Rewitalizacja a praca socjalna w środowisku miejskim, [w:] Organizowanie społeczności lokalnej: aplikacje, wdrażanie, przyszłość, red. B. Gruszka, Warszawa 2014, s. 28. 
mieszkańców. Idea ta wpłynęła na zmianę podejścia władz do zarządzania jednostkami miejskimi. Postępująca demokratyzacja sprawiła, że głos mieszkańców zaczął być słyszalny, co zainicjowało mobilizację do stowarzyszania się w grupy walczące o dopuszczenie do współkreowania swojej przestrzeni, a co za tym idzie samych siebie ${ }^{58}$.

Takie nieformalne, lokalne inicjatywy oddolne nazwano ruchami miejski$m i^{59}$. Ich działanie charakteryzuje się zachowaniem koncepcji zrównoważonego miasta, czyli takiego korzystania z zasobów, które pozwoli realizować potrzeby obecnych mieszkańców, a jednocześnie umożliwi to kolejnym pokoleniom. Ruchy miejskie odwołują się również do idei slow cities czy też nowego urbanizmu, w których wartości społeczne i przestrzenne postawione są ponad zyskiem ekonomicznym. Jedną z pryncypialnych zasad przyjmowanych przez ruchy miejskie jest estetyzacja przestrzeni. Dążą one także do tworzenia harmonijnego krajobrazu, w którym ludzie będą się dobrze czuć. P. Wolski pisze, że

poczucie wspólnoty zależy w dużej mierze od ładu przestrzennego. (...) bezpośrednio oddziałuje na człowieka, determinuje jego poglądy, postawy, określa relacje społeczne, daje poczucie bezpieczeństwa i wzmacnia przywiązanie do miejsca ${ }^{60}$.

Na takim podejściu budowane są działania edukacyjne dla społeczności lokalnych, prowadzone przez ruchy miejskie. Uświadamiają one, jak miasto wpływa na jego mieszkańców i jak umiejętnie wchodzić w interakcję z miastem. Tak też, jak się nam zdaje, budowane powinny być zasoby dla koncepcji city-based learning. By to było jednak możliwe, potrzebne są zaawansowane rozwiązania technologiczne i naukowo opracowane strategie pedagogiczne. Tymi kwestiami planujemy zająć się w nowym projekcie naukowym, który realizowany będzie na Wydziale Studiów Edukacyjnych Uniwersytetu im. Adama Mickiewicza w Poznaniu w najbliższych latach.

Podziękowania. Część dotycząca tła koncepcji city-based learning opiera się na pracy dyplomowej napisanej przez pierwszego autora pod kierunkiem prof. zw. dr hab. Agnieszki Gromkowskiej-Melosik, zatytułowanej Miasto. Konteksty społeczne i pedagogiczne, obronionej na Wydziale Studiów Edukacyjnych Uniwersytetu im. Adama Mickiewicza w Poznaniu w 2018 roku. 2015.

${ }^{58}$ C. Ampatzidou i in., The hackable city: a research manifesto and design toolkit, Amsterdam s. 160.

59 J. Śpiewak, Ruchy miejskie ucza biznes nowoczesności, Studia Pedagogiczne, 2016, LXIX,

${ }^{60}$ P. Wolski, Cele i zasady gospodarowania krajobrazem, [w:] Polska polityka architektoniczna. Polityka jakości krajobrazu, przestrzeni publicznej, architektury, red. K. Chwalibóg, Warszawa 2018, s. 42. 
Pozostałe części wykorzystują analizy realizowane przez drugiego autora w ramach grantu European Cooperation in Science and Technology (COST): Fostering knowledge about the relationship between Information and Communication Technologies and Public Spaces supported by strategies to improve their use and attractiveness (CYBERPARKS) (TUD COST Action TU1306). COST jest częścią EU Framework Programme for Research and Innovation Horizon 2020. Autorzy deklarują równy wkład w powstanie niniejszej pracy.

\section{BIBLIOGRAFIA}

Aletta F., Van Renterghem T., Botteldooren D., Influence of personal factors on sound perception and overall experience in urban green areas. A case study of a cycling path highly exposed to road traffic noise, International Journal of Environmental Research and Public Health, 2018, 15.

Ampatzidou C., Bouw M., van de Klundert F., de Lange M., de Waal M., The hackable city: a research manifesto and design toolkit, Amsterdam 2015.

Batagan L., Smart cities and sustainability models, Informatica Economica, 2011, 15.

Bonanno P., Klichowski M., Lister P., A pedagogical model for CyberParks, [w:] CyberParks - the interface between people, places and technology, red. C. Smaniotto Costa, I. Suklje-Erjavec, Springer 2018.

Caragliu A., Del Bo C., Nijkamp P., Smart cities in Europe, Journal of Urban Technology, 2011, 18.

Cooley S.J., Holland M.J., Cumming J., Introducing the use of a semi-structured video diary room to investigate students' learning experiences during an outdoor adventure education groupwork skills course, Higher Education: The International Journal of Higher Education and Educational Planning, 2014, 67.

Copik I., Pedagogika miejsca - kultura lokalna a ksztattowanie się tożsamości wspótczesnego człowieka, [w:] Pedagogika, t. XXII, red. K. Rędziński, M. Łapota, Częstochowa 2013.

Cretu L.G., Smart cities design using event-driven paradigm and semantic web, Informatica Economica, 2012, 16.

Czornik M., Miasto i jego produkty, Studia Ekonomiczne, 2013, 147.

Danilewicz W., Doświadczenia miejsca w przestrzeni globalnej - perspektywa pedagogiczna, [w:] Pedagogika społeczna. Pamięć: przeszłość - teraźniejszość - przyszłość, red. W. Danilewicz, W. Theiss, Warszawa 2016.

Gaj M., Kamińska K., Miasto - nowe pogranicze. Wyzwania dla krytycznej pedagogiki miejsca, [w:] Miejskie opowieści edukacyjne narracje przestrzeni, red. K. Kamińska, Wrocław 2010.

Gong L., Mao B., Qi Y., Xu C., A satisfaction analysis of the infrastructure of country parks in Beijing, Urban Forestry \& Urban Greening, 2015, 14.

Gontar B., Gontar Z., Pamula A., Deployment of smart city concept in Poland. Selected aspects, Management of Organizations: Systematic Research, 2013, 67.

Gonzalez-Martinez J.A., Bote-Lorenzo M.L., Gomez-Sanchez E., Cano-Parra R., Cloud computing and education: a state-of-the-art survey, Computers \& Education, 2015, 80.

Goswami P., Matrix for a smart city, Current Science, 2015, 109.

Gruenewald D., The Best of Both Worlds: A Critical Pedagogy of Place, Educational Researcher, 2003,32 . 
Hajduczenia J., Przestrzeń i edukacja: podróż edukacyjna jako rytuat przejścia, Teraźniejszość Człowiek - Edukacja: kwartalnik myśli społeczno-pedagogicznej, 2009, 3.

Hajduk S., The concept of a smart city in urban management, Business, Management \& Education, 2016, 14.

Harvey D., Bunt miast. Prawo do miasta i miejska rewolucja, Warszawa 2012.

Hung P.-H., Hwang G.-J., Lin Y.-F., Wu T.-H., Su I-H., Seamless connection between learning and assessment-applying progressive learning tasks in mobile ecology inquiry, Educational Technology \& Society, 2013, 16.

Igoe D., Parisi A., Carter B., Smartphones as tools for delivering sun-smart education to students, Teaching Science: The Journal of the Australian Science Teachers Association, 2013, 59.

Jałowiecki B., Miasto $i$ społeczne problemy urbanizacji, problemy, teorie, metody, Warszawa 1972.

Jałowiecki B., Przedmowa, [w:] Miasto jako przedmiot badań naukowych w początkach XXI wieku, red. B. Jałowiecki, Warszawa 2008.

Jałowiecki B., Wspólne i odrębne płaszczyzny badań, [w:] Miasto jako przedmiot badań naukowych w początkach XXI wieku, red. B. Jałowiecki, Warszawa 2008.

Jałowiecki B., Miejsce, przestrzeń, obszar, Przegląd Socjologiczny, 2011, 2.

Jałowiecki B., Czytanie przestrzeni, Kraków - Rzeszów - Zamość 2012.

Jang S., Study on service models of digital textbooks in cloud computing environment for SMART education, International Journal of $\mathrm{u}$ - and e- Service, Science and Technology, 2014, 7.

Jeong J.-S., Kim M., Yoo K.-H., A content oriented smart education system based on cloud computing, International Journal of Multimedia and Ubiquitous Engineering, 2013, 8.

Kamińska K., Wstęp. O dyskursach edukacyjnych w przestrzeni miejskiej, [w:] Miejskie wojny. Edukacyjne dyskursy przestrzeni, red. K. Kamińska, Wrocław 2011.

Khatoun R., Zeadally S., Smart cities: concepts, architectures, research opportunities, Communications of the ACM, 2016, 59.

Kim B.H., Oh S.Y., A study on the SMART education system based on cloud and n-screen, Journal of the Korea Academia-Industrial Cooperation Society, 2014, 15.

Kim J.-K., Sohn W.-S., Hur K., Lee Y.-S., Effect of enhancing learning through annotation similarity and recommendation system, International Journal of Smart Home, 2013, 7.

Kim S.H., Park N.H., Joo K.H., Effects of flipped classroom based on smart learning on self-directed and collaborative learning, International Journal of Control \& Automation, 2014, 7.

Klichowski M., Learning in CyberParks. A theoretical and empirical study, Poznan 2017.

Klichowski M., Learning in hybrid spaces as a technology-enhanced outdoor learning: Key terms, [w:] Neighbourhood \& City - Between digital and analogue perspectives, red. M. Menezes, C. Smaniotto Costa, Lisbon 2018.

Klichowski M., Bonanno P., Jaskulska S., Smaniotto Costa C., de Lange M., Klauser F., CyberParks as a new context for smart education: theoretical background, assumptions, and pre-service teachers' rating, American Journal of Educational Research, 2015, 3.

Klichowski M., Smaniotto Costa C., How do pre-service teachers rate ICT opportunity for education? A study in perspective of the SCOT theory, Culture and Education, 2015, 4.

Klichowski M., Patricio C., Does the human brain really like ICT tools and being outdoors? A brief overview of the cognitive neuroscience perspective of the CyberParks concept, [w:] Enhancing Places through Technology. Proceedings from the ICiTy conference, red. A. Zammit, T. Kenna, Lisbon 2017.

Kourtit K., Nijkamp P., Arribas D., Smart cities in perspective - a comparative European study by means of self-organizing maps, Innovation: The European Journal of Social Sciences, 2012,25 . 
Kraus S., Richter C., Papagiannidis S., Durst S., Innovating and exploiting entrepreneurial opportunities in smart cities: evidence from Germany, Creativity \& Innovation Management, 2015, 24.

Land S.M., Zimmerman H.T., Socio-technical dimensions of an outdoor mobile learning environment: a three-phase design-based research investigation, Educational Technology Research and Development, 2015, 63.

Lewicka M., Psychologia miejsca, Warszawa 2012.

Mendel M., Kategoria miejsca w pedagogice, [w:] Pedagogika miejsca, red. M. Mendel, Wrocław 2006.

Mendel M., Pedagogika miejsca i animacja na miejsce wrażliwa, [w:] Pedagogika miejsca, red. M. Mendel, Wrocław 2006.

Mendel M., Społeczeństwo i rytuat. Heterotopia bezdomności, Torun 2007.

Mendel M., Rewitalizacja a praca socjalna w środowisku miejskim, [w:] Organizowanie społeczności lokalnej: aplikacje, wdrażanie, przyszłość, red. B. Gruszka, Warszawa 2014.

Miciukiewicz K., Miasto jako spoteczna reprodukcja przestrzeni $i$ kontrprzestrzeni miejsc, [w:] Pedagogika miejsca, red. M. Mendel, Wrocław 2006.

Mone G., The new smart cities, Communications of the ACM, 2015, 58.

Murai K., Hayashi Y., Stone L.C., Inokuchi S., Basic evaluation of performance of bridge resource teams involved in on-board smart education: lookout pattern, Review of the Faculty of Maritime Sciences, Kobe University, 2006, 3.

Paszkowski Z., Miasto idealne w perspektywie europejskiej i jego zwiazki z urbanistyką wspótczesna, Kraków 2011.

Perez-Sanagustin M., Parra D., Verdugo R., Garcia-Galleguillos G., Nussbaum M., Using $Q R$ codes to increase user engagement in museum-like spaces, Computers in Human Behavior, 2016, 60.

Popow M., Organizacje pozarzadowe, miasta i zmiana społeczna, Studia Pedagogiczne, 2016, LXIX.

Powierzchnia i ludność w przekroju terytorialnym w 2018 r., Warszawa 2018.

Quak H., Lindholm M., Tavasszy L., Browne M., From freight partnerships to city logistics living labs - giving meaning to the elusive concept of living labs, Transportation Research Procedia, 2016, 12.

Samadi Z., Yunus R.M., Omar D., Bakri A.F., Experiencing urban through on-street activity, Procedia - Social and Behavioral Sciences, 2015, 170.

Segiet K., Miasto, [w:] Wielka encyklopedia pedagogiczna XXI wieku, t. II, red. E. Różycka, Warszawa 2004.

Semanjski I., Gautama S., Smart city mobility application - gradient boosting trees for mobility prediction and analysis based on crowdsourced data, Sensors, 2015, 15.

Smith C., Bradley C., Cook J., Pratt-Adams S., Designing for active learning: putting learning into context with mobile devices, [w:] Informed design of educational technologies in higher education: enhanced learning and teaching, red. A.D. Olofsson, J.O. Lindberg, Hershey 2012.

Śpiewak J., Ruchy miejskie ucza biznes nowoczesności, Studia Pedagogiczne, 2016, LXIX.

Su C.-H., Cheng C-H., A mobile gamification learning system for improving the learning motivation and achievements, Journal of Computer Assisted Learning, 2015, 31.

Theiss W., Dom i ojczyzna - miejsca w świecie bez miejsc. Trzy perspektywy, [w:] Dom i ojczyzna dylematy wielokulturowości, red. D. Lalak, Warszawa 2008.

Thite M., Smart cities: implications of urban planning for human resource development, Human Resource Development International, 2011, 14.

Tong H., Feng Y., Smart education and legal governance, 3rd International Conference on Science and Social Research, 2014. 
Tranos E., Gertner D., Smart networked cities? Innovation: The European Journal of Social Sciences, 2012, 25.

Tuan Y-F., Space and place, London 1977.

Wolański N., Miasto jako przedmiot badań ekologii człowieka, [w:] Miasto jako przedmiot badań naukowych - refleksje po 10 latach, red. B. Jałowiecki, Katowice 1982.

Wolski P., Cele i zasady gospodarowania krajobrazem, [w:] Polska polityka architektoniczna. Polityka jakości krajobrazu, przestrzeni publicznej, architektury, red. K. Chwalibóg, Warszawa 2018.

Ya'acob A., Nor N., Azman H., Implementation of the Malaysian smart school: an investigation of teaching-learning practices and teacher-student readiness, Internet Journal of e-Language Learning \& Teaching, 2005, 2. 